\title{
NEOLITHIC DISPERSAL IN FAR NORTHEAST EUROPE: WAYS AND CHRONOLOGY
}

\author{
Victor N Karmanov ${ }^{1} \cdot$ Natalia E Zaretskaya $^{2} \cdot$ Evgenia L Lychagina $^{3}$
}

\begin{abstract}
By analyzing archaeological evidence and radiocarbon dates, we studied the Neolithization of Far Northeast Europe (Russian Perm' region, Komi Republic, and Nenets autonomous district). Our study shows that this process in the eastern European forest zone was rather ambiguous. Taking into account the periodicity of settling and short duration of residence here, the term "Neolithization" in its traditional sense cannot be applied to some territories in this region. For instance, the emergence of ceramics--the most important feature of Neolithization here-did not affect considerably the way of life of the ancient population, which continued the traditions of the Mesolithic hunter-gatherers well into the Early Neolithic. Such attributes as heat treatment of clay paste and siliceous rocks for changing physical features of natural materials, bifacial knapping, and construction of subterranean dwellings represent the archaeological evidence of Neolithization in the region.
\end{abstract}

\section{INTRODUCTION}

Neolithization is traditionally considered a process of expansion of producing economies or, for the forest zone of eastern Europe, the skills of producing ceramic ware (pottery). The latter parameter, though formal, has a great importance because "the invention of ware resulted from the transition to sedentism and especially from the change of the whole economy and way of life of the population" (Oshibkina 1996:6; authors' translation of the original Russian). This was an "epochal event, which changed considerably vital activities of ancient communities. Alongside with the strengthening of technical and economic potential (production of the first artificial material, preservation of reserves), it stimulated and formed creative abilities of the human" (Shumkin 2003:277; authors' translation of the original Russian).

We therefore focus on the chronology and ways of Neolithization in Far Northeast Europe (FNEE). We describe the main features of this process based on a critical analysis of archaeological evidence as well as by comparing our data to those contained in Mesolithic and synchronous Neolithic assemblages from adjacent territories.

\section{STUDY AREA}

Far Northeast Europe (FNEE) is a geographical region limited in the north by the Barents Sea coast, in the east by the Ural Mountains, in the south by the latitudinal fragment of the Kama River valley, and in the west by the Severnaya Dvina River. Administratively, this region includes the Komi Republic, the Nenets autonomous district, and the province of Perm', Russian Federation (Figures $1,2)$. The large area with its heterogeneous geological structure and relief foster great environmental diversity inside the region: the northernmost part of the region is in the tundra zone, while the western part is in taiga. Geomorphologically, FNEE is separated into 2 parts: the eastern margin reaches into the Ural Mountains, while the western part belongs to the Russian Plain. The region is characterized by its dense drainage network divided into 4 main river basins: Vychegda (North Dvina basin); Kama (Volga basin); Mezen'; and Pechora.

\footnotetext{
'Institute of Language, Literature and History of Komi Science Center of Ural Division of Russian Academy of Sciences, Kommunisticheskaya st., 26, Syktyvkar 167982, Republic of Komi, Russian Federation. Corresponding author. Email: vkarman@bk.ru.

${ }^{2}$ Geological Institute of Russian Academy of Sciences, Pyzhevsky per., 7, Moscow 119017, Russia.

${ }^{3}$ Perm State Pedagogical University, Sibirskaya str., 24, Perm' 614990, Russia.
}

(C) 2012 by the Arizona Board of Regents on behalf of the University of Arizona Proceedings of the 6th International Radiocarbon and Archaeology Symposium, edited by E Boaretto and N R Rebollo Franco RADIOCARBON, Vol 54, Nr 3-4, 2012, p 331-338 


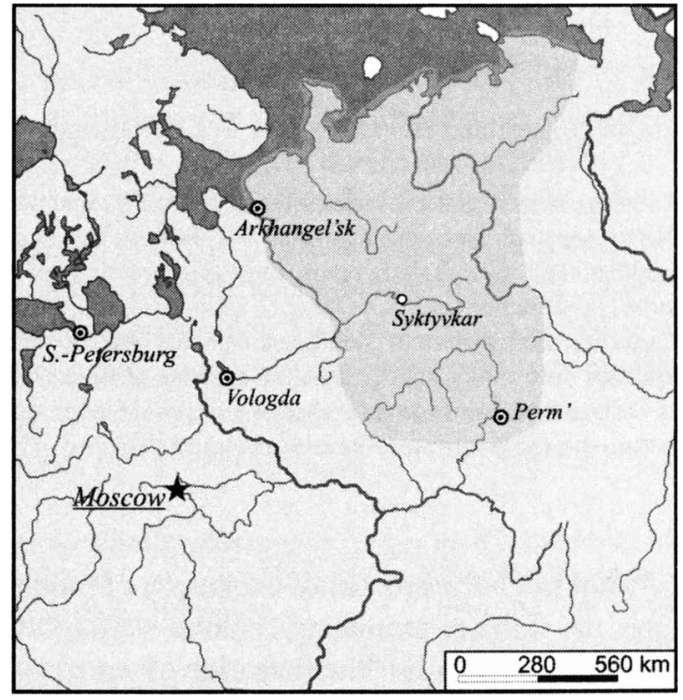

Figure 1 Study area: Far Northeast Europe (FNEE)

\section{MATERIALS AND METHODS}

Research of the Neolithic in Far Northeast Europe (FNEE) dates back about a century, with the discovery and excavation of $\sim 100$ Neolithic sites. These studies mainly focused on establishing the chronological affinity of the sites as well as their cultural affiliation; the mechanisms of culture type formation have also been researched. Cultural-chronological maps of the regional Neolithic have been composed from previous studies (Burov 1967, 1974, 1986; Kosinskaya 1997; Karmanov 2008; Vereshchagina 2010). Generally, on the basis of ceramic studies, 6 groups of culturally different sites and 2 main directions of cultural development and relationships in the region have been defined: southwestern (the development area of Neolithic cultures of the Volga-Oka interfluve, Middle and Upper Volga region) and southeastern (Kama River basin). Cultural relationships with Fennoscandia (Burov 1986) and western Siberia (Kosinskaya 2000) have also been hypothesized.

According to the proposed views, Neolithic dispersal in FNEE is connected either to migrations or to cultural relationships between the regional population and adjacent areas. However, the differences notwithstanding, these views agree that this region has been continuously populated since the Mesolithic. Based on this conviction, most archaeologists envisaged the alternating inhabitation of heterocultural population groups in the same territory (Burov 1993; Kosinskaya 2000:185).

Critical analysis of current archaeological evidence allows for reliable selection of sites that contain authentic materials that are trustworthy enough to characterize the material culture of the Neolithic population. These criteria apply to 26 of 110 currently known sites (see Table 1). Other collections are used for background information and for site mapping as well as for determining the distribution of ceramic ware and/or stone tools (Karmanov 2008).

Radiocarbon dating of the Neolithic sites here is limited due to the lack of well-preserved samples as a consequence of certain peculiarities of sediment geochemistry and, probably, of the short-term human occupation of known Neolithic sites in FNEE. It should be noted that, until 2003, there was only $1{ }^{14} \mathrm{C}$-dated assemblage: the Prilukskaya site (Volokitin and Karmanov 2000). In the last decade, however, $\sim 42{ }^{14} \mathrm{C}$ dates have been obtained for 18 total FNEE sites, including Pezmog 4 


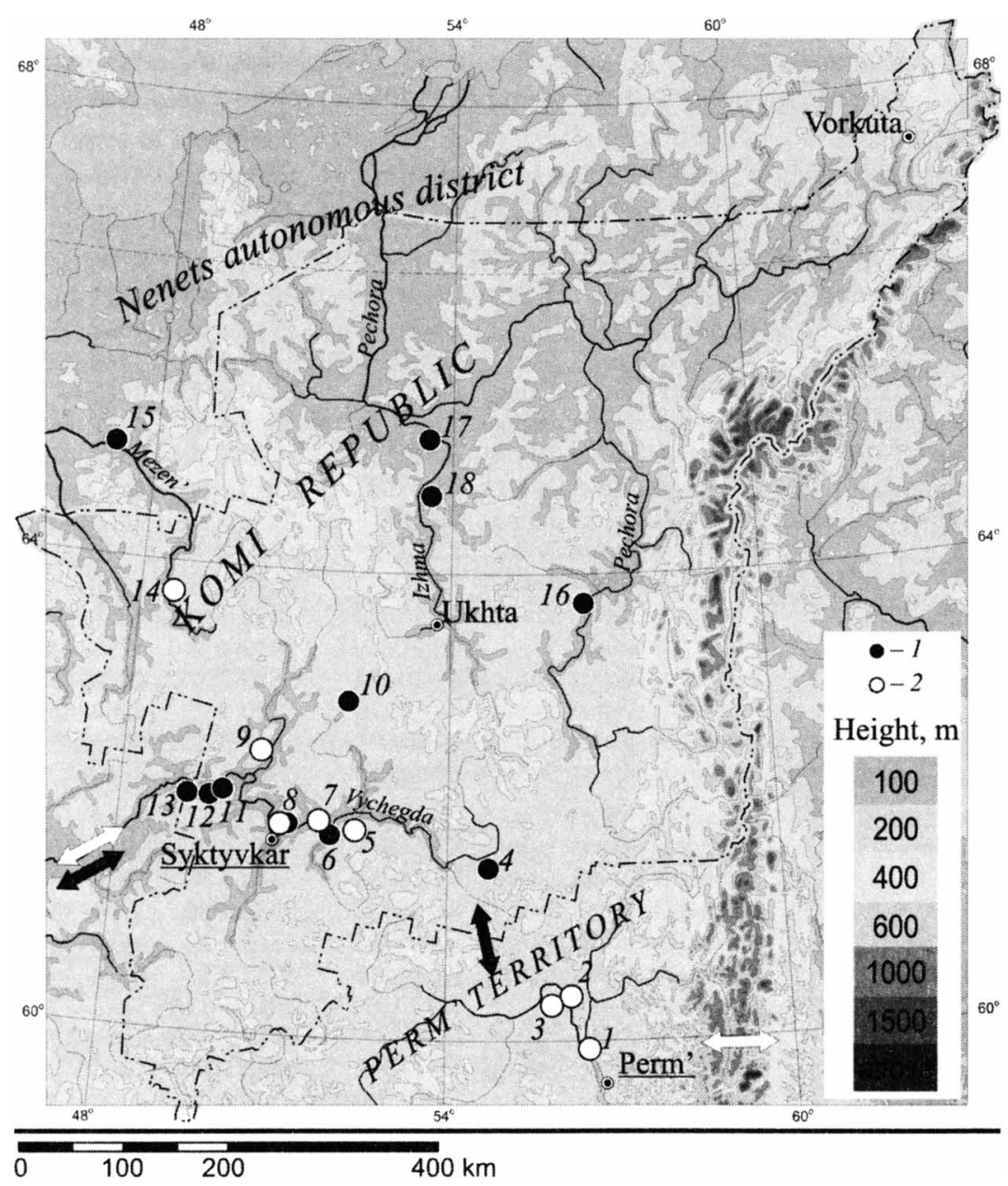

Figure 2 Distribution of reference sites and possible pathways of population movements (marked by arrows), Mesolithic and Early Neolithic (black dots); Middle and Late Neolithic (white dots). Sites mentioned in the text: 1) Borovoe Ozero I; 2) Hutorskaya; Chashkinskoe Ozero I, IV, VI, VIII; 3) Ust'-Zalaznushka; 4) Parch 2; Cherdyb 1, 2; 5) Vad 1; 6) Pezmog 4; 7) Pezmogty 1, Pezmogty 3, Pezmogty 4, Pezmogty 5; 8) En'ty $1,3,6$; 9) Polovniki 2; 10) Vis 1-3; 11) Kochmas B; 12) Revyu 1; 13) Chernaya Vadya; 14) Kystyryu; 15) Koneshel'e; 16) Dutovo 1; 17) Chernoborskaya 3; 18) Lek-Lesa 1.

(foodcrust, wood charcoal, culture-bearing deposits, direct dating of ceramic); Dutovo I (bone char); Prilukskaya (wood charcoal, direct dating of ceramic); En'ty 1a, 3 (direct dating of ceramic); Pezmogty 1 (wood charcoal); Vis 2 and Chojnovty 1 (wood charcoal). Most of the Kama sites have been dated by the direct dating of ceramic fragments. Exceptions are Khutorskaya, Chernushka, and Chashkinskoye Ozero 4 and 6, where charcoal samples have been obtained (Table 1).

Most samples were dated conventionally at the Geological Institute of the Russian Academy of Sciences in Moscow (lab code GIN) and the Institute of History of Material Culture in Saint Petersburg (lab code Le), using standard pretreatment procedures (Zaretskaya et al., these proceedings). 
Table 1 Radiocarbon results for the sites studied. Calibration was done using Reimer et al. (2009) data.

\begin{tabular}{|c|c|c|c|c|c|}
\hline Site & Dated material & Lab code & $\begin{array}{l}{ }^{14} \mathrm{C} \text { date } \\
(\mathrm{BP})\end{array}$ & $\begin{array}{l}\text { Age cal BC } \\
1 \sigma(68.2 \%) \\
\end{array}$ & $\begin{array}{l}\text { Age cal BC } \\
2 \sigma(95.4 \%)\end{array}$ \\
\hline \multicolumn{6}{|l|}{ Middle and Late Neolithic ${ }^{a}$} \\
\hline Hutorskaya, excavation of 2006 & Wood charcoal & SOAN-6818 & $4990 \pm 110$ & $3962-3706$ & $4053-3628$ \\
\hline Hutorskaya, excavation of 2006 & Wood charcoal & SOAN-6817 & $5040 \pm 130$ & $3962-3706$ & $4053-3628$ \\
\hline Hutorskaya, excavation of 2006 & Wood charcoal & GIN-14226 & $5130 \pm 250$ & $4250-3650$ & $4500-3300$ \\
\hline Hutorskaya, excavation of 2006 & Potsherds (direct dating) & Ki-14419 & $5840 \pm 80$ & $4790-4590$ & $4860-4490$ \\
\hline Chojnovty 1 & Wood charcoal & Le-1729 & $5320 \pm 60$ & $4235-4146$ & $4269-4036$ \\
\hline Chojnovty 1 & Wood charcoal & Le-2168 & $5210 \pm 60$ & $4060-3958$ & $4184-3941$ \\
\hline Chernushka & Wood charcoal & GIN-13449a & $5400 \pm 70$ & $4340-4220$ & $4360-4040$ \\
\hline Kryaghskaya & Potsherds (direct dating) & $\mathrm{Ki}-14416$ & $5620 \pm 90$ & $4540-4350$ & $4690-4320$ \\
\hline Chashkinskoe Ozero VI & Potsherds (direct dating) & $\mathrm{Ki}-14538$ & $5695 \pm 80$ & $4620-4450$ & $4720-4350$ \\
\hline Chashkinskoe Ozero I & Potsherds (direct dating) & $\mathrm{Ki}-16166$ & $5700 \pm 80$ & $4620-4450$ & $4720-4360$ \\
\hline Hutorskaya, dwelling 1 & Potsherds (direct dating) & $\mathrm{Ki}-15093$ & $5750 \pm 80$ & $4690-4490$ & $4790-4440$ \\
\hline Hutorskaya, dwelling 1 & Potsherds (direct dating) & $\mathrm{Ki}-14414$ & $5930 \pm 80$ & $4860-4710$ & $5000-4590$ \\
\hline Borovoe Ozero I & Potsherds (direct dating) & $\mathrm{Ki}-14415$ & $5760 \pm 90$ & $4720-4490$ & $4810-4440$ \\
\hline Chernashka & Potsherds (direct dating) & $\mathrm{Ki}-16645$ & $5840 \pm 90$ & $4800-4580$ & $4860-4490$ \\
\hline Pezmogty 1 & Potsherds (direct dating) & $\mathrm{Ki}-16657$ & $5690 \pm 80$ & $4618-4451$ & $4705-4364$ \\
\hline Pezmogty 1 & Wood charcoal & GIN-11914 & $5840 \pm 100$ & $4798-4554$ & $4938-4483$ \\
\hline Ust'-Zalaznushka & Potsherds (direct dating) & $\mathrm{Ki}-14417$ & $5880 \pm 80$ & $4850-4670$ & $4940-4540$ \\
\hline Hutorskaya, dwelling 2 & Potsherds (direct dating) & $\mathrm{Ki}-14420$ & $5920 \pm 90$ & $4860-4680$ & $5030-4540$ \\
\hline Borovoe Ozero I & Potsherds (direct dating) & $\mathrm{Ki}-15094$ & $5950 \pm 80$ & $4940-4710$ & $5050-4610$ \\
\hline Chernushka & Potsherds (direct dating) & Ki-14418 & $5960 \pm 80$ & $4940-4770$ & $5060-4670$ \\
\hline \multicolumn{6}{|l|}{ Early Neolithic } \\
\hline Vis 2 & Potsherds (direct dating) & $\mathrm{Ki}-16034-2$ & $4840 \pm 90$ & $3712-3518$ & $3799-3490$ \\
\hline Vis 2 & Potsherds (direct dating) & Ki-16034-1 & $5370 \pm 90$ & $4329-4224$ & $4356-3989$ \\
\hline En'ty $1 \mathrm{~A}$ & Potsherds (direct dating) & $\mathrm{Ki}-16032$ & $4930 \pm 80$ & $3794-3641$ & $3946-3631$ \\
\hline En'ty $1 \mathrm{~A}$ & Potsherds (direct dating) & $\mathrm{Ki}-15534$ & $5625 \pm 80$ & $4526-4365$ & $4619-4336$ \\
\hline Chashkinskoe Ozero VI & Potsherds (direct dating) & $\mathrm{Ki}-14536$ & $5755 \pm 90$ & $4710-4490$ & $4810-4440$ \\
\hline Chashkinskoe Ozero VI & Wood charcoal & GIN-13275 & $6030 \pm 140$ & $5080-4720$ & $5300-4600$ \\
\hline Chashkinskoe Ozero VI & Wood charcoal & GIN-13276 & $6230 \pm 160$ & $5370-4990$ & $5500-4750$ \\
\hline Chashkinskoe Ozero IV & Potsherds (direct dating) & $\mathrm{Ki}-14539$ & $5920 \pm 80$ & $4860-4690$ & $5000-4580$ \\
\hline Chashkinskoe Ozero IV & Wood charcoal & GIN-13449 & $6160 \pm 70$ & $5220-5020$ & $5310-4930$ \\
\hline Chashkinskoe Ozero VIII & Potsherds (direct dating) & $\mathrm{Ki}-14537$ & $5770 \pm 90$ & $4720-4500$ & $4810-4440$ \\
\hline Chashkinskoe Ozero VIII & Potsherds (direct dating) & $\mathrm{Ki}-15095$ & $6310 \pm 90$ & $5380-5200$ & $5480-5050$ \\
\hline Prilukskaya & Potsherds (direct dating) & $\mathrm{Ki}-16174-1$ & $6170 \pm 90$ & $5223-4996$ & $5319-4896$ \\
\hline Prilukskaya & Potsherds (direct dating) & $\mathrm{Ki}-16207$ & $6220 \pm 90$ & $5300-5195$ & $5374-4936$ \\
\hline Prilukskaya & Wood charcoal & Le-4814 & $6350 \pm 60$ & $5380-5294$ & $5394-5220$ \\
\hline Prilukskaya & Potsherds (direct dating) & $\mathrm{Ki}-16174-2$ & $6370 \pm 90$ & $5471-5297$ & $5493-5206$ \\
\hline Prilukskaya & Wood charcoal & Le-4813 & $6680 \pm 70$ & $5646-5540$ & $5709-5490$ \\
\hline Dutovo 1 & Bone char & GIN-14009a & $6680 \pm 50$ & $5640-5557$ & $5674-5511$ \\
\hline Pezmog 4 & Potsherds (direct dating) & Ki-15428-2 & $6130 \pm 100$ & $5212-4951$ & $5307-4830$ \\
\hline Pezmog 4 & Potsherds (direct dating) & Ki-15428-1 & $6410 \pm 90$ & $5472-5320$ & $5544-5213$ \\
\hline Pezmog 4 & Wood charcoal & GIN-12322 & $6730 \pm 50$ & $5676-5617$ & $5724-5603$ \\
\hline Pezmog 4 & Cultural deposit & GIN-12324 & $6760 \pm 50$ & $5712-5630$ & $5749-5558$ \\
\hline Pezmog 4 & Foodcrust & GIN-11915 & $6820 \pm 70$ & $5754-5637$ & $5849-5617$ \\
\hline \multicolumn{6}{|l|}{ Mesolithic } \\
\hline Zaposel'e & Wood charcoal & GIN-13448a & $7300 \pm 50$ & $6218-6152$ & $6250-6051$ \\
\hline Cherdyb 2 & Wood charcoal & GIN-13358 & $7460 \pm 70$ & $6399-6327$ & $6457-6213$ \\
\hline Cherdyb 1 & Wood charcoal & GIN-13357 & $7520 \pm 90$ & $6457-6344$ & $6534-6216$ \\
\hline Lek-Lesa 1 & Wood charcoal & Le-3607 & $9010 \pm 70$ & $8298-8198$ & 8334-7957 \\
\hline Parch 2, dwelling 6 & Wood charcoal & GIN-11913 & $9100 \pm 250$ & $8640-7940$ & $8855-7598$ \\
\hline Parch 2, dwelling 5 & Wood charcoal & GIN-11912 & $9500 \pm 250$ & $9226-8560$ & $9469-8233$ \\
\hline
\end{tabular}

aPeriodization is represented according to archaeological data. 
Dating of ceramic samples was conducted by the Kiev ${ }^{14} \mathrm{C}$ laboratory following the methods developed by Kovaliukh and Skripkin (2007). The direct dating of potsherds was recently used to establish an absolute chronology of the Neolithic assemblages within the steppe zone (Vybornov 2008) where no other types of samples for ${ }^{14} \mathrm{C}$ dating are available. However, our experience shows a considerable discrepancy between the ceramic dates and those obtained from other samples and archaeological data (Table 1). In the case of older ceramic dates, we explain this discrepancy by the presence of older organics in the clay paste: Neolithic people could use materials such as organic silts (often containing shells) when preparing this paste. We consider it impossible to separate older and synchronous carbon during the dating process. Ceramic dates that are younger than others obtained from the same archaeological item require more analysis: probably, contamination of potsherds by younger carbon could occur during the postdepositional period. Thus, the dating of bulk organic matter from the sample (as described in Kovaliukh and Skripkin 2007), without removing the exterior parts of sherds, likely resulted in "mixed" dates. Several paired dates (obtained from the same sample) demonstrate huge discrepancies and force us to question the methods of sample cleaning: $\mathrm{Ki}-16034-1$ (5370 $\pm 90 \mathrm{BP})$ and Ki-16034-2 (4840 $\pm 90 \mathrm{BP})$; Ki-16174-1 (6170 $\pm 90 \mathrm{BP})$ and Ki$16174-2$ (6370 $\pm 90 \mathrm{BP})$; and Ki-15428-2 (6130 $\pm 100 \mathrm{BP})$ and Ki-15428-1 (6410 $\pm 90 \mathrm{BP})$.

\section{RESULTS AND DISCUSSION}

The results of comparative-typological analysis and ${ }^{14} \mathrm{C}$ dating allow us to distinguish at least 2 habitation periods during the Neolithic (Figure 3). The early period dates from $6870 \pm 40$ (GIN-14202) to $6130 \pm 90 \mathrm{BP}(\mathrm{Ki}-15428-2)$, or $5800-4960 \mathrm{cal} \mathrm{BC} .{ }^{4}$ During this period, different small population groups from the central part of Russian Plain and the Middle Cis-Ural region emerged.

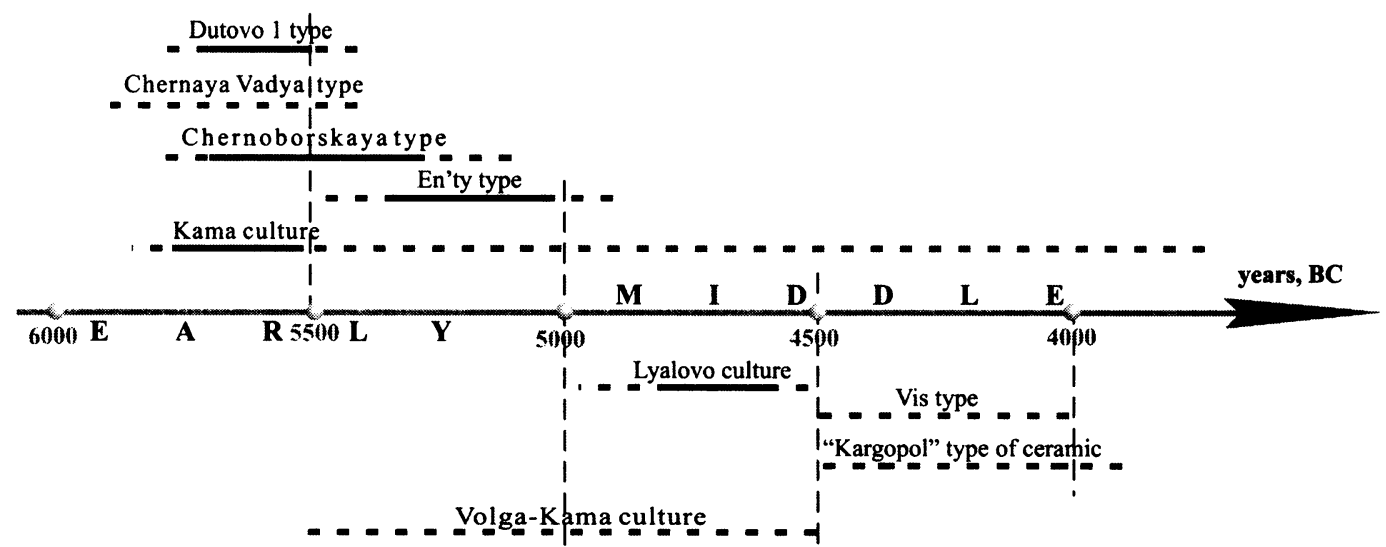

Figure 3 FNEE Neolithic: chronology and periodization

The next stage seems related to the penetration of pit-comb ceramic tradition bearers; this tradition originated from the Lyalovo culture in the central part of the Russian Plain (Sidorov 1992; Sidorov and Engovatova 1997). The known sites with pit-comb ceramics represent a rather narrow chronological period from $5840 \pm 100$ (GIN-11914) to $5690 \pm 80 \mathrm{BP}(\mathrm{Ki}-16657)$, or $4800-4360 \mathrm{cal} \mathrm{BC}$. This corresponds to the first 2 stages of the Lyalovo culture (Engovatova 2000). Synchronously with the pit-comb ceramic tradition, the comb-shaped and pinhole ceramic traditions existed within the southeastern part of the study area. The periods of these cultures' existence (5060-3630 cal BC for 
comb-shaped and $5480-4440$ cal $\mathrm{BC}$ for pinhole) are quite large. We suggest that this can be explained first by the contamination of Neolithic layers by younger material (Chalcolithic, etc.) and second by the lack of dates obtained on well-preserved samples such as foodcrust, bones, wood artifacts, etc. Further dating should sharpen this period from both sides.

The main features of Neolithization can be defined only by comparing them to the main peculiarities of the local Mesolithic. We compared those features that can be reflected in the present archaeological data. An analysis of the sites' distribution on the regional map shows that all the sites are "scattered" across the vast area (Figure 2). Thus, the Chernoborskaya group occupied the valleys of Izhma, Mezen, Vychegda, and northern Dvina. The distance between the 2 ultimate points (Prilukskaya and Chernoborskaya 3) is $550 \mathrm{~km}$. Analogues of materials from Chernoborskaya were discovered in the basin of the Sukhona River at the Beresova Slobodka II-III and VI sites (Ivanisheva 2006), $720 \mathrm{~km}$ from the Chernoborskaya 3 site.

In comparison to the Early Neolithic sites, Middle Neolithic sites are more numerous and located throughout the FNEE area, including the Bolshezemelskaya tundra. The distance between 2 ultimate sites (Marmugino and Pechorskaya) within the region is about $900 \mathrm{~km}$. However, the distribution of the most expressive sites is limited at the northeast by the Timan Ridge, and most sites are concentrated near oxbow (Middle Vychegda, Kama) and watershed lakes (such as Sindor, Yamoozero, Kosminskie, Pinezhskie, Krasny Okun lakes). Middle Vychegda sites are distinguished by their small settlements with 1 to 5 dwellings and are mostly located within the $60-\mathrm{km}$-long valley.

Usually, the Mesolithic and early Neolithic camps were situated on the second fluvial terraces or on the eolian dunes of the first fluvial terraces. On the contrary, the Middle Neolithic dwellings were constructed on the lower levels of the first fluvial terraces. Dwellings as an element of the subsistence system are characteristic for both periods. However, for the Mesolithic and Early Neolithic, light, portable, and aboveground constructions were typical. Semi-subterranean dwellings as well as more substantial dwellings were a common feature of the Middle Neolithic. As a rule, all of these domestic units occurred in places with single-stage habitation within a season.

We note that reference collections of Mesolithic-Neolithic assemblages do not differ in their quantitative characteristics. We usually study 2000-3000 artifacts (without microdebitage and undefined small potsherds and bone fragments) and 100-200 flint tools per assemblage. The amount of pots is about 3-5 per Neolithic complex. Tools for hunting and further processing of hunting products represent the toolkits of Mesolithic-Neolithic assemblages.

The most considerable changes over time occurred in flint technology knapping, with the main trend from microblade industries to bifacial knapping. This trend is expressed in the thinning of massive or twisting areas of ventral faces of blanks (Dutovo 1), bifaces with completely processed dorsal faces, and the selective processing of massive areas of the ventral face (Chernoborskaya 3 ). In the industry of En'ty 1a, the biface production stands out as an independent knapping type that kept blade chip-blanks. In Lyalovo-type sites, the bifacial knapping becomes primary, though the blade knapping technique was preserved. This technique, however, was no longer serial and it was rather selective. Moreover, one of the main features of mid-Neolithic flint knapping is the use of heat treatment of raw partings for improving their quality.

Fauna assemblages, which are represented by calcified bone fragments, do not differ across the sites and Stone Age periods: the elk-beaver-reindeer trio persisted not only during the MesolithicNeolithic but also well into the Bronze and Early Iron ages. Therefore, the Early Neolithic population in the FNEE followed the traditions of their Mesolithic precursors--as hunters, gatherers, and 
fishers. In addition, the mid-Neolithic settlers of the region exploited the natural resources of the northern forests, too, but their adaptive possibilities were higher due to such innovations as bifacial knapping; heat treatment of flint raw; usage of ceramic; and subterranean, substantial dwellings.

\section{CONCLUSIONS}

Data analysis (number of sites, collection volumes, characteristics of cultural layers, and typological composition of artifacts) points to a short-term seasonal habitation at the known sites within the study area. During the Neolithic, these were mainly hunting camps; long-term settlements were not typical in this period. Over the middle stage, despite the appearance of dwellings, artifacts found inside them are also few in numbers. This fact suggests one-time habitation within a season. We must note the relatively low population density and periodicity of settling in the region. For instance, the period between 5500-4000 cal BC lacks any reliable archaeological evidence.

Site mapping by certain cultural formations and correlations between ${ }^{14} \mathrm{C}$ dates has shown that this region was a nature management area for the populations studied. In this aspect, the term "Neolithization" for some areas should be "updated," taking into account some new features. For instance, the appearance of the earliest ceramics in the period 5850-5200 cal BC did not affect considerably the way of life of the ancient population, which continued the traditions of Mesolithic hunters and gatherers. On the other hand, such skills as heat treatment of clay and siliceous rocks for modification of physical features of natural materials improved the adaptive possibilities of the Neolithic populations in northern Eurasia. These attributes as well as bifacial knapping and construction of subterranean dwellings represent real archaeological evidence of Neolithization. However, according to current data, this process was not limited to the early Neolithic only, and it continued until the time the pit-comb bearers spread in the region between 4900 and 4500 cal BC. It should be noted that the first reliable evidence of farming and breeding - the economic aspects of Neolithizationcoincide with the Russian colonization of northeast Europe at the end of the 14th century AD. In general, the analyzed archaeological data confirm the ideas of Thomas (2003) about the Neolithic as "a range of various processes, generating considerable variability of subsistence practices." Finally, we are convinced that the direct ${ }^{14} \mathrm{C}$ dating of potsherds should be controlled, wherever possible, by dates obtained from other sample types, because the organic components of the ceramic paste are still poorly known.

\section{ACKNOWLEDGMENTS}

We would like to thank Alexander Vybornov, DSc, for his kind help in organizing the direct dating of our ceramic samples. The research was partly supported by the Russian Foundation for Basic Research (projects 11-06-09209-mob_z, 11-06-00337-a, and 11-05-00538-a).

\section{REFERENCES}

Burov GM. 1967. Drevniy Sindor (Istoriia plemen Evropeyskogo Severo-Vostoka $v 7$ tys. do n.e. -1 tys. n.e. [Ancient Sindor (History of tribes of European North-East in 7 th millennium BC - 1st millennium AD)]. Moscow: Nauka Publishing. 220 p. In Russian. Burov GM. 1974. Archeologicheskie cultury Evropeiskogo Severa SSSR (Severodvinsky Region): Istoricheskaya kniga dlia studentov [Archaeological cultures of European North of the USSR (Severodvinsky Region): History Student's Book]. Ulyanovsk: Ulyanovskiy State Pedagogical Institute Press. 120 p. In Russian.
Burov GM. 1986. Krayniy Evropeiskiy Severo-Vostok v Mesolite, Neolite and v Epohu Rannih Metallov: Avtoreferat Doctorskoy Dissertatsyi [Extreme NorthEast of Europe in the Mesolithic, Neolithic and Early Metal Age: Abstract of Doctoral Thesis]. Novosibirsk: Novosibirsk State University Press. 37 p. In Russian.

Burov GM. 1993. Neo-, eneoliticheskie poluzemlyanki na krainem severo-vostoke Evropy kak elementy social'noi organizacii drevnego naseleniya [Neoeneolithic subterranean dwellings of Far North-East of Europe as elements of social organization of ancient 
population]. In: Kovaleva VT, Kosinskaya LL, editors. Voprosy Archeology Urala. Volume 21. Ekaterinburg: Ural State University Press. p 23-41. In Russian. Engovatova AV. 2000. Hronologiya epohi neolita VolgoOkskogo Mejdurech'ya [Chronology of Neolithic of Volga-Oka interfluve]. In: Timofeev VI, editor. Hronologia neolita Vostochnoy Evropy. Abstracts of International Conference Dedicated to the Memory of Prof. N.N. Gurina. Saint Petersburg: Institute of Material Culture of Russian Academy of Sciences. p 94. In Russian.

Ivanisheva MV. 2006. Ranniy neolit Nigney Suhony (na osnove issledovania stoianki Berezova Slobodka) [Early Neolithic of Lower Suhona River (case study of Berezova Slobodka sites)]. In: Archeologia: Istoria $i$ Perspectivy. Yaroslavl. p 85-105. In Russian.

Karmanov VN. 2008. Neolit Evropeyskogo SeveroVostoka [Neolithic of European North-East]. Syktyvkar: Komi Science Center UD RAN Press. 226 p. In Russian.

Kosinskaya LL. 1997. Neolit [Neolithic]. In: Savel'eva EA, editor. Archeologia Respubliki Komi. Moscow: DiK Publishing. p 91-146. In Russian.

Kosinskaya LL. 2000. Svyazi v neolite Evropeiskogo Severo-Vostoka i Zapadnoi Sibiri [Neolithic relations between European North-East and Western Siberia]. In: Savel'eva EA, editor. Korennye etnosy Evropeiskoi chasti Rossii na poroge novogo tysyacheletiya: istoriya, sovremennost', perspektivy. Syktyvkar: Komi Science Center UD RAN press. p 181-5. In Russian.

Kovaliuk N, Skripkin V. 2007. Radiouglerodnoe datirovanie arheologicheskoi keramiki jidkostnym scintillyacionnym metodom [Radiocarbon dating of archaeological ceramic by liquid scintillation counting]. In: Zaitseva GI, Kul'kova MA, editors. Radiouglerod v arheologicheskih $i$ paleoekologicheskih issledovaniyah: materialy konferencii. Posvyaschennoi 50letiyu radiouglerodnoi laboratorii IIMK RAN. Saint Petersburg: Teza Publishing. p 120-6. In Russian.

Oshibkina SV. 1996. Neolit. Vvedenie [Neolithic. Introduction]. In: Oshibkina SV, editor. Arheologia. Neolit Severnoy Evrazii. Moscow: Nauka Publishing. p 610. In Russian.

Reimer PJ, Baillie MGL, Bard E, Bayliss A, Beck JW, Blackwell PG, Bronk Ramsey C, Buck CE, Burr GS, Edwards RL, Friedrich M, Grootes PM, Guilderson TP, Hajdas I, Heaton TJ, Hogg AG, Hughen KA, Kaiser KF, Kromer B, McCormac FG, Manning SW, Reimer RW, Richards DA, Southon JR, Talamo S, Turney CSM, van der Plicht J, Weyhenmeyer CE. 2009.
IntCal09 and Marine09 radiocarbon age calibration curves, 0-50,000 years cal BP. Radiocarbon 51(4): 1111-50.

Sidorov VV. 1992. Mnogosloynye poseleniia basseyna Verhney Volgi Varos i Yazykovo [Multilayer Varos and Yazykovo sites in Upper Volga Basin]. In: Mnogosloynye poseleniia Verhney Volgi. Moscow. p 4-113. In Russian.

Sidorov VV, Engovatova AV. 1997. Drevnie ohotniki i rybolovy Moscovskogo Regiona (po datirovkam mnogosloynogo poselenia kamennogo i bronzovogo vekov Voymezhnoe I [Ancient hunters and fishers of Moscow Region (according to data of Voymezhnoe I multilayer settlement of Stone and Bronze Ages)]. Moscow: Institute of Archaeology of Russian Academy of Sciences. 292 p. In Russian.

Shumkin VY. 2003. Keramika Drevnego Naselenia Kolskogo Poluostrova (K Voprosu o Neolitizatsii Severnoy Evropy) [Ceramics of ancient population of the Kola Peninsula (to the problem of Neolithization in Northern Europe)]. In: Timofeev VI, editor. NeolitEneolit Yuga $i$ Neolit Severa Vostochnoy Evropy (novye materialy, issledovaniia, problemy regionalnoy neolithizatsii). Saint Petersburg: Institute of Material Culture of Russian Academy of Sciences Press. p 277-98. In Russian.

Thomas J. 2003. Thoughts on the 'repacked' Neolithic revolution. Antiquity 77(295):75-86.

Vereshchagina IV. 2010. Mesolit i Neolit Kraynego Evropeiskogo Severo-Vostoka [Mesolithic and Neolithic of extreme European North-East]. Saint Petersburg: Peterburgskoe Vostokovedenie Publishing. 232 p. In Russian.

Volokitin AV, Karmanov VN. 2000. Problemy chronologii neolita Evropeiskogo Severo-Vostoka [Problems of chronology of the Neolithic of European North-East]. In: Timofeev VI, editor. Hronologia neolita Vostochnoy Evropy. Abstracts of Reports of the International Conference Dedicated to the Memory of Prof. N.N. Gurina. Saint Petersburg: Institute of Material Culture of Russian Academy of Sciences. p 812. In Russian.

Vybornov AA. 2008. New data on radiocarbon chronology of Neolithic ceramics from the Volga-Kama region. Archaeology, Ethnology and Anthropology of Eurasia 4:15-24.

Zaretskaya NE, Hartz S, Terberger T, Savchenko SN, Zhilin MG. 2012. Radiocarbon chronology of the Shigir and Gorbunovo archaeological bog sites, Middle Urals, Russia. Radiocarbon, these proceedings. 